論文

\title{
ネットワーク型コミュニティの成立とその機能 世田谷区プレーパーク活動を事例として—
}

The Development and Function of a Network Community:

A Case Study of Activities in the Setagaya Play Park

\section{小山弘美}

\section{Hiromi KOYAMA}

The purpose of this paper is to clarify how a network of voluntary associations can develop inside or outside a local community, and to identify the functional properties of the network. This study focused on activities observed in the Setagaya play park, in Tokyo. The authors found that collaborative relationships with the local community or government were best fostered by longterm activities that were initiated by a region-specific problemsolving volunteer-based association. Through organizational cooperation and by virtue of the characteristics of activity participants, a network community that is focused on regionspecific problems can be established. The network community is not required to remain inside a given region but could be expanded to Japan and the world. The social capital generated by the network community is available to the local community through voluntary associations that link people in the network.

\section{1. 問題の所在}

これまで、幾度となくコミュニティの重要性が指摘され、再生が問題とされてきた。近 年でも、東日本大震災など大災害に見舞われた時の避難や復興の場面において、一般的に も地域の絆やつながりが重要であることが指摘される。また、学術的にもソーシャル・キャ ピタル論などで、コミュニティ再生の有用性が指摘されている $[\mathrm{Putnam}, 2000=2006]$ 。 国の政策としても、地域包括ケアシステムなど、地域のつながりを前提とした地域福祉シ ステムが目指され、互助・共助を担うことができる地域づくりが提唱されている1 。

都市社会学において、このようなコミュニティの再組織化に関する議論はかなりの蓄積 があるが、議論し尽くされているかといえばそうではない。コミュニティの状況は時代に よって変化し続けているのであり、常に現況を捉えながら、今日的な説明とその普遍性の 探求を継続せねばならない。そのような大きな変化を捉えたものとして、B. ウエルマン のコミュニティ問題の提起 $[1979=2006]$ を挙げることができる。ウェルマンは、コミュ ニティ概念の要素のうち地域性を必要条件から外したが、その指摘通り、今日共同性を共 
有する集団や親密な人間関係は、地域の中で完結していることなど想像できない。ウェル マンは通信や交通手段の発達によりコミュニティの状況が変化したとするが、現在のITC 環境の発達はこれを加速させている。コミュニティ概念にとって、地域性はますます前提 できないものになっていると言えるだろう。

しかしながら一方で、コミュニティの必要性が問われる際には、地域性を前提としたコ ミュニティが想定される場合が多い。大災害発災時の緊急避難や長期的な復興の過程にお いても、地域コミュニティの重要性が指摘される [倉田, 1999 ; 今野, 1999]。しかし、そ の重要性はもちろん認められるとしても、先の指摘のように人びとが日ごろ関わりを持つ 集団や親密な人間関係は、地域の中にとどまっているものではない。多くの人びとにとつ て、地域外に拡がる親族ネットワークや、知人・友人のネットワークこそ被災時に大きな 助けとなるのである ${ }^{2)}$ 。これと同様に、地域コミュニティにとっても、地域内にとどまら ない地域外の組織や人びととのネットワークが、被災時などに重要な役割を担うものと考 えられる゙)。しかも、そのようなネットワークは日常的な相互行為のなかで蓄積されてい るものであり、通常時から地域外に拡がるネットワークを把握しておくことが求められ る。しかしこれまで、地域構造を把握する際、あくまで地域内の組織やネットワークの把 握に偏向してきたのではないだろうか。分析の枠組みを地域に限定せず、地域外に拡がる ネットワークやコミュニティについて研究を行う必要性がここに現れる。

日本の都市社会学において、コミュニティの再組織化が最初に問題となっていたのは、 1970 年代である。地域社会における都市化の状況を受け、地縁を基盤とする関係や集団 の衰退・変容の状況が問題とされ、これまでの地域社会に代わる「新しく期待される地域 社会」として「コミュニティ」が標榜された ${ }^{4)}$ 。この頃のコミュニティ論の代表的な論者 である奥田道大 [1971] は、コミュニティの範域は、地理的に想定されるというよりも、 意識や行動の共通性によって設定されるものであるとする。ここで定義の上では、すでに コミュニティの必要条件として地域性が前提とされていないことが指摘できる。奥田は地 域社会の分析枠組みにおいて、コミュニティの要件を「住民の主体化」と「価值の普遍 化」においている。しかし、これらは実際には与件とはなりえず、住民が地域社会におい て相互行為を行いながら徐々に獲得していかねばならない。そこで、奥田のコミュニティ 形成に向けた展開は、特殊的課題解決のための組織（住民運動）が、地域における総体的・ 普遍的な問題を引き受けていくというものであった [奥田, 1975]。

一方、越智昇はボランタリー・アソシエーションが触媒の役割を果たし、既存の組織を 変容させるというコミュニティ形成の展開を考えていた [越智, 1982]。それは、ボランタ リー・アソシエーションの参加者の自己変革が、共同主体の確立へとつながると同時に、 地域の既存組織や、それが担ってきた地域管理機能と対峙せざるを得なくなるからであ る。ところで、1980年代のボランタリー・アソシエーションやこれに関わる人びとにとつ て、現在の市民活動やNPOの興隆に向けて重要な意味を持っていたのは、ネットワーキ 
ング運動 [Lipnack and Stamps, $1982=1984]$ である。異なる特殊的課題を持つた運動同士 が、大きな枠組みの中では同様の目的を持っていたということが確認され、全国的なネッ トワークを組むことで、変革の力を生むことが認識されるようになつた [高田, 1998]。こ れに対して越智は、日本の地域においてネットワーキングを考える際には、既存の地域住 民組織を無視できないとする [越智, 1986]。ボランタリー・アソシエーションのメンバー が地域において第一次的ネットワークを築き、地域になくてはならない人になることに よって、既存の地域住民組織を変革させていく。越智が考えるコミュニティ形成のプロセ スは、地域外でのネットワーキングを前提としたボランタリー・アソシエーションが、地 域の中のネットワークに組み込まれることによって既存組織を変容させ、新しい地域コ ミュニティを形成するというものであった。

奥田や越智のコミュニティ形成論は、住民運動やボランタリー・アソシエーションなど 特殊的課題解決型のアソシエーションが、地域コミュニティの形成にいかに寄与するかを 扱つたものと整理できる。分析の枠組みは地域範囲内となっており、きわめてオーソドッ クスな地域コミュニティ研究として位置づけられる。しかし、特に越智はその前提として いたように、住民運動や市民活動・NPOの特殊的課題解決型のアソシエーションは、多 くの場合、その課題解決のための地域に限定されないネットワークを形成していくものと して捉えうる。これらのアソシエーションが地域の中でネットワークを造成し、地域コ ミュニティ形成に寄与していくと想定されていたように、地域の外でもその特殊的課題解 決のためのネットワークが造成され、コミュニティが形成されていくと考えることができ るのではないか。これが本稿の扱うネットワーク型コミュニティである。

このネットワーク型コミュニティは、特殊的課題に特化したアソシエーションと同一視 されるべきではない。その違いについて、奥田のコミュニティの要件としての普遍化や、 越智が日本の地域社会の文化型と捉えている「分担」の議論は示唆的である。分担とは、 他のことをすることなしに自分のことを満足にすることはできないという思想・態度であ り [越智, 1982]、ネットワーキング運動はボランタリー・アソシエーションにおける分担 の展開と捉えることができる。つまりネットワーキングは、アソシエーションが他の課題 をも解決しない限り、自分たちの問題も解決できないと認識させた運動だったのであり、 生活課題の総体を問題化してコミュニティを形成していつた過程と捉えることができるの である。ここで、特殊的課題解決のためのネットワーク型コミュニティは、特殊的課題解 決を第一義の目的に置きながら、これに関わる普遍的・総体的な生活課題をも引き受けて いくものとして特徵づけることができる。そしてこのネットワーク型コミュニティは、地 域の内部にも造成されるものであり、また地域の外部にも拡がりを持つものである。

本稿では、特殊的課題解決型のアソシエーションが織りなすネットワークに注目するこ とによって、地域内外に拡がるネットワーク型コミュニティの成立を描き出し、その機能 を明らかにしていく。そのために、子どもの遊びや遊び場を問題として活動を展開・継続 
させてきた、東京都世田谷区のプレーパーク活動の事例分析を試みる。次節以降で詳述す る通り、世田谷区のプレーパーク活動は、特殊的課題解決型のアソシエーションとして出 発したが、今日までの 40 年の間に地域内外にネットワークを拡充させて、普遍的・総体的 な生活課題との関わりを深め、結果としてネットワーク型コミュニティを成立させるに至つ ている事例と位置づけられるからである。それでは以下に詳しく見ていくことにしよう。

\section{2. 地域内でのネットワーク型コミュニティの形成}

\section{1 世田谷におけるプレーパーク活動の開始}

世田谷区は東京 23 区の西南に位置し、人口は 88 万人と 23 区内で 1 番多い自治体であ る。戦後 31 万人だった人口は 1970 年には 70 万人を超えて倍増し、その後バブル経済期に 若干減少したが、1995年以降は再び増加を続けている [世田谷区, 2017］。落ち着いた住宅 地が拡がり、周辺の他区市とともに山の手地区に分類することができる地域である。1975 年に区長公選制が復活し当選した革新系の大場啓二氏のもと、1978年の世田谷区基本構想 で住民主体のまちづくりが掲げられ、特徵的なコミュニティ行政を行ってきた。これと共 鳴しながら、特色ある多様な住民主体の市民活動が育ってきたが、なかでもプレーパーク 活動は、行政と 40 年近くにも渡り協働してきた歴史を持つ。

プレーパーク活動の発端は、アレン卿夫人の『都市の遊び場』[1968=1973]の翻訳を 行った大村虔一・璋子夫妻が、本で紹介されている遊び場の視察を行つたことである。帰 国後に近隣の幼稚園や小中学校で、ヨーロッパ各地の「冒険遊び場」のスライドを上映し 仲間を集めた。冒険遊び場とは、火を焚いてパンケーキを焼いたり、小屋をつくったりす るなど、子どもたち自身がしたいと思うことを自由にできる遊び場である。子どもたちの 遊びや遊び場の変化に危機感を抱いていた親たちが賛同し、1975年 6 月に「遊ぼう会」を 発足させた。同年と翌年の夏休夕に、経堂の空き地で冒険遊び場を開催し、1977年 7 月か らは桜丘の区民センター予定地で、15か月間常設で遊び場を開催した [羽根木プレーパー クの会, 1987]。

冒険遊び場には、子どもの遊びを見守りエンパワメントするプレーリーダーが常駐して いる。経堂の遊び場は夏休み期間限定であり、プレーリーダーを担うボランティアの大学 生が常時参加できたが、桜丘では運営を担う母親たちもローテーションで常駐しなければ ならず、常設になることで運営側の負担が格段に増した。資金をバザーや古紙・空き午回 収で集めるなどの苦労もあったが、特に地域住民でもある運営の母親たちを悩ませたの は、「污い」「危ない」といつた近隣からの苦情や批判であった。1978年 9 月に桜丘の冒険 遊び場が閉幕した時、土地を貸していた世田谷区は継続してもよいという意向を持ってい たが、自分たちの力だけで継続することは無理だと感じていた [羽根木プレーパークの 会, 1987]。 
翌年、遊ぼう会の運営者と冒険遊び場の実績と意義を評価した世田谷区公園課の職員と の働きかけにより、世田谷区の国際児童年の記念事業として、世田谷区立羽根木公園の一 画で「羽根木プレーパーク」が開設されることになった。プレーパークは行政が管理する 公園で行う冒険遊び場のことであり、行政と協働して運営していくことが前提となる。そ のため開設の準備会には、遊ぼう会のメンバーに加え、世田谷区から公園課、児童課、社 会教育課が参加した。1979年 7 月に羽根木プレーパークが開設されると、住民と行政が協 働で行う取り組みとしてメディアで多数取り上げられ、全国から視察が訪れるなど成功し、 事業の継続が決定した。1981年には区の働きかけにより世田谷公園に 2 つ目のプレーパー クである世田谷プレーパークが開設された。その後も区の基本計画や実施計画に位置づけ られた上で、新たなプレーパークの設置が目指され、1989年に駒沢はらつぱプレーパー ク、2003年に烏山プレーパークが開設されてきた [羽根木プレーパークの会, 1987]。この ように区の施策に取り入れられた背景として、コミュニティ行政の影響でプレーパークの ような住民主体の活動が評価される土壌があったことを指摘できる。

\section{2 行政や地域からのアクセプト}

羽根木プレーパーク開設当時、住民が本当にしつかりやれるのか、事故の際の責任はど うなるのかなど、運営を担う住民に対し世田谷区は不安を抱いていた。手づくりの遊具や 活動に対して、多くの区民から苦情が区に寄せられていたことも不信感を募らせた。しか し実際に子どもたちが目を輝かせて遊ぶ光景があり、メディアにも大きく取り上げられ、 住民主体の活動で予算が低く抑えられたことなどが継続の要因となった [NPO 法人プレー パークせたがや研修センター, 2013]。

プレーパークの運営者は、近隣からのクレームなどには行政で対応せずに、必ず自分た ちで対応するようにしてきた。これは、区が対応してしまえば禁止事項ばかりになってし まうからである。このように一貫して活動の責任をとつてきた姿勢も区からの信頼を得る 一因となった。2つ目の世田谷プレーパーク設立の際、何かあれば行政がすぐ対応できる よう、公園管理事務所を存する公園で行うことが絶対条件となっていた [小山, 2018]。こ れに対し、3つ目の駒沢はらつぱと 4 つ目の鳥山は住民の活動が先にあつたものを区の事 業として認めていつたもので、この絶対条件も外れていつた。このことからも、行政の団 体に対する信頼感の変化を読みとることができる。

1985 年に羽根木プレーパークの敷地の縮小を含む公園改修計画が、プレーパークの実行 委員会に相談することなく一方的に発表されるということがあった。この時プレーパーク 側は、区と協働で運営していくためのルールの確立が必要との認識をもつた一方で、計画 の地元説明会では近隣住民からプレーパークへの苦情が噴出し、区と一緒にこれらの苦情 に対処した [羽根木プレーパークの会, 1987]。このように、団体と区は時に対抗的に、時 に協力的に事業を進めてきたと考えることができる。 
一方、地域の中においても冒険遊び場やプレーパークの活動は異端であった。桜丘の冒 険遊び場時代、「污い」「危険だ」という非難が地域に根強くあり、これは羽根木プレー パークの開設当時も変わらなかつた。桜丘の経験をふまえ、羽根木プレーパーク開設の際 には、地元小中学校のPTA役員や町内会長に呼び掛けて準備会に参加してもらった。設 立後も、地域の町内会役員、PTAや青少年対策の関係者、区役所の出張所や公園職員など に声をかけ、手芸や野外料理をしながら語り合う交流の場を設けて継続していつた [羽根 木プレーパークの会, 1987]。バザーなどのイベント時には、事前に地域の人びとへ一品 無料券をつけた招待券を配布した。その他にも、御用聞きのように最近困ったことはない かと近隣を訪ね、たまたま電球替えを手伝うなどすると、そこからは苦情が来なくなつた [NPO法人プレーパークせたがや研修センター, 2013]。プレーパークが常設で継続される ことになり、騒音に関することなど近隣からの苦情も多かつたなかで、子どもの遊び場に ついて理解を広げるために、意識的に地域と交流を深めてきた。このような地道な活動に より、少しずつ地域の中で受け入れられていつた。

1983 年頃には清掃やイベントの手伝いにさまざまな人たちが手を貸してくれるように なっていた。プレーパークで遊んだ経験のある子どもが増えてくる中で、小学校のPTA 活動にプレーパークのイベントの手伝いが組み入れられるケースも生まれた。地域の中で プレーパークに対する苦情が消えるわけではなかったが、活動や趣旨に賛同し暖かく見 守っている人が少しずつ増えていき、1985年 10 月時点で登録会員数は 140 名にのぼっ た。このようにプレーパーク活動の輪は着実に拡がり、多くの子どもたちと地域の大人た ちが関わる団体に成長していつたのである [羽根木プレーパークの会, 1987]。

羽根木プレーパーク開設から 40 年近くたつた現在は、地域の活動として当たり前の存 在になっている。かつては、不良のたまり場と思われるなど学校との距離があったが、少 しずつ対応も変化し、最近は学校との関係が良好になり、授業で子どもたちがプレーパー クに来たり、プレーカーで学校に出張したりすることもある。特別支援学校や児童館とも 一緒にイベントを行っている。プレーパークは基本的に地元の住民が運営しているので、 自然と町内会とも人のつながりがある。プレーパークの運営に関わつている人はPTAの 役員を引き受ける人も多く、地域の役である青少年委員や青少年地区委員などをその後担 う人もいる。こうした地域の子どもに関する役を引き受けた後、町内会役員を担う人もい る [小山, 2018]。こうしてメンバーを介して、プレーパークが地域コミュニティのネット ワークの中に埋め込まれているのである。

\section{3 プレーパークの機能拡大}

プレーパークの今日的意義は、遊び場としての一般的なイメージにとどまらず、多様な 人びとの交流の場となり、不登校児などの問題を抱える子どもの居場所ともなっている。 近年は保護につながる被虐待児を発見するケースも増えていることが世田谷区からも認識 
され、4プレーパークが地域ごとの要保護児童支援協議会にも参画している。プレーパー クやプレーパークに関わる人びとが、子どもを見守る重要な機能を担っていることが、地 域や行政にも認識されている状況となっている。

このように子どもの遊びや遊び場以外の問題に意識的に取り組むようになつた大きな転 換点は、団体がNPO法人化したことである。それまでは、世田谷区がプレーパーク事業 を民間組織である世田谷ボランティア協会に委託し、実際には地域住民で構成されている 世話人会が各プレーパークを運営してきた。2003 年に世田谷区内 4 か所のプレーパーク が、合同でNPO法人プレーパークせたがやを設立し、その後はNPO法人が区と直接委託 契約を結び運営している。NPO法人化後は、遊び場の運営にとどまらず、思春期の子ど もたちの居場所づくりなど新事業を立ち上げてきた。普段の夕食が外食や個食になってし まっている子がいるというプレーリーダーの気づきから、中高生の子どもたちと一緒に夕 食をたき火で作って食べる活動を始めた。これまでも中高生や若者と一緒に、夕飯を作っ て食べるといつたことを実際には行っていたが、NPO法人化後は、そのことの社会的意 義を認識して発信し、区や地域の承諾を得ながら行っているという変化がある [小山, 2018]。

乳幼児期の子どもと子育てに目が向くようになったのも、NPO法人化した頃からで あった。子育て環境の変化により、子育てが子どもと親だけの関係になってしまっている ことに危機感を抱き、乳幼児期の子育て支援について世話人が意識するようになつた。し かし、小さな子ども連れはおむつを替える場所やゆっくりと休める場所がないと遊びに来 ることが難しい。そこで、乳幼児の授乳やおむつ替えのための建物として、「そらまめハ ウス」を2011年に羽根木プレーパーク内に完成させた。これと並行して、全国で初めて の「屋外型」子育て支援拠点として認めてもらうため、世田谷区子ども部、国土交通省、 厚生労働省と一緒に話し合ってきた。2015年 4 月にこれが認められ、地域子育て支援拠点 事業として補助金を受けて運営を行っている。このように新事業の意義をきちんと発信 し、区や地域と連携しながら行っていくという姿勢はNPO 法人となった後の特徽として 指摘できる [小山, 2018]。これらの活動以外にも、既存のプレーパークを飛び出し、世田 谷区内の他の公園で遊び場活動を行うプレーカー事業や被災地支援を行うことによって、 新しい場所や地域で子どもの遊びや遊び場に関するネットワークをつくりだしている。

\section{4 担い手のネットワークと役割——羽根木プレーパークSさんの事例}

これまでは、団体としての活動の始まりから、地域の中で認められネットワークやその 機能を拡大してきた様子を見てきた。ここでは、1人の活動者が活動に参加することでど のように主体化し、ネットワークを拡大させ、どのような役割を担うのかという点に着目 したい。羽根木プレーパークの世話人として 1990 年くらいから 25 年以上関わってきた $\mathrm{S}$ さんは、現在地域の代表として小学校統合の話し合いに参加し、民間発の世田谷コミュニ 
ティ財団立ち上げの発起人になるなど、世田谷の市民活動を引つ張っていくような人物の 1 人となっている。プレーパークの世話人やプレーリーダーとして団体に関わり、その後 自分の興味関心の中で活動の場を拡げていく例は多い。ここでは、Sさんをこうした事例 の典型として取り上げることにしたい ${ }^{5)}$ 。

$\mathrm{S}$ さんは 3 人の子どもたちとプレーパークに関わってきた。長男が育てにくかったこと が羽根木プレーパークとの出会いにつながった。3 歳くらいではじめてプレーパークに 行った時、そこにいた自主保育の子どもたちは、かみつかれたら自分もやりかえすような 感じで、周りの母親たちも大げさな反応をせず、気持ちが楽になった。そこで自分も自主 保育に参加し、係としてプレーパークの世話人を引き受けることになった。世話人会で は、自主的に「できることはやります」という雾囲気を面白いと思い、そのまま活動には まった。「活動の意義に共感して」といつた強い思いがあるというより、基本的には遊び ながら関わつてきたという。

活動に関わり始めた 1990 年当時は、プレーパークに来る人も少なく活動自体がマイ ナーで、好きな人が楽しめればいいという時代だった。しかしNPO法人化した現在は、 プレーパーク活動が「みんなにとつて必要だ」ということを自覚してきたという。各新聞 で様々な切り口から、プレーパークのような場所が必要だというふうに取り上げられてい る。これらを受けて「もしかしたら、本当にいろんな意味で、何かを変えていくとか、突 破できるような鍵の一つではあるのかもしれない」と思うようになつた。ある時、大学の 研究者から「日本でこれから社会を担っていく子どもたちの育ちのために、この取組みは 続けてもらわなければ困る」と言われた。Sさんとしては、自分のため、自分たちのた め、地域のためというふうに思っていたが、こうした活動が本当に重要だと言われて納得 したという。そういうことなら、自分たちも拡げていく努力をしなくてはいけない。それ は、子どもたちのためにも、大人のためにも必要であり、社会のためにも必要なのかもし れないと思うようになつた。

$\mathrm{S}$ さんは、NPO法人の新事業である屋外型子育て支援拠点事業のための「そらまめハウ ス」建設の際、中心的に立ち回ったうちの 1 人である。公園の中に建物を建てることは法 的な規制があり難しい中で、区の担当課がアイデアを出し工夫を凝らして協力してくれた 結果、建築許可をとることができた。プレーパーク運営に関わるなかでこうした世田谷区 との対等な協働関係を経験し、そういう体制がつくれると考えるようになり、2000年くら いから子どもたちが通う小学校で校庭づくりの活動を行つてきた。教諭、職員、保護者、 地域住民が参加する地域に開かれた組織を立ち上げ、ワークショップを行うなどして校庭 づくりをすすめた [大村編, 2009]。Sさんは学校が地域の核になり、PTAを卒業した親た ちも含めた地域住民がこれを支え、学校のネットワークから地域もフィードバックが得ら れるような図式になればという思いで活動してきた。

この小学校を含めた 3 校を 1 校に統合する計画があり、Sさんは地元の説明会に町内会 
長代理として出席してきた。Sさんによれば、教育委員会は学校の適正規模を根拠に統合 を進めたい考えだが、地域住民は防災のことを心配しているのだという。小学校は防災の 拠点となっているため避難所としては残すというが、PTAが入って来ないなかで、どのよ うにコミュニティをつくるのかということが問題となる。しかしながら、結局話し合いは 平行線のまま打ち切りとなり、3 校は統合されることになった。木造密集地域として知ら れる周辺地域にとって、災害時の拠点になるはずの小学校をなくすか否かという問題は、 教育の視点からの夕考えるべきではないとSさんは述べている。

PTA活動に長く関わってきたSさんは、現在は青少年地区委員を担い、町内会活動でも 班長を担うなご、積極的に地域の役割を担っている。活動の出発点はプレーパークである が、子どもに関する地域の役を積極的に担ってきた。だからこそ、地域の子どもたちの問 題として浮上してきた小学校統合の話し合いに、町内会長代理として出席しているのであ る。そのSさんは、子どものためという狭い視点からではなく、地域コミュニティ全体に 関わる問題意識をもって、このような会議に参加していることがうかがえる。

\section{5 地域内のネットワーク型コミュニティの成立}

これまで見てきたように、プレーパーク活動は、子どもの遊びや遊び場の変化に危機感 を抱いた人びとが、行政と信頼関係を築き、地域との軋㧛を少しずつ解消しながら継続し てきた。現在は子どもの遊びだけでなく、子どもに関して見守りなどの機能を担い、地域 や行政からもそのような役割が是認されている。組織としての学校や児童館などとの連 携、世話人が地域の役を担うことによる地域住民組織との連携など、子どものことに関わ るネットワークの中に、プレーパークおよびその担い手が組み込まれている。こうした ネットワークによって、運営者やプレーリーダーが活動の中で気がついた子どもを取り巻 く問題に直接対処したり、他の組織や人びとにつなげたりしているのである。遊びや遊び 場を問題とするアソシエーションを成立させているだけでなく、子どもの生活に関わる総 体的な課題に対峙し、それらに関わるネットワークと接続することによって、子どもの問 題に関するコミュニティの形成に寄与していることが読み取れる。こうしてネットワーク 型コミュニティが地域の中に成立することにより、ネットワークの線上にいない人びと も、いつの間にか見守られていたり、何かあったら相談できたりするのである。

アソシエーションが他の問題をも対象にしていく過程には、担い手の問題関心やネット ワークも重要になる。Sさんは、子どもの遊びに関する課題をもつ当事者として、自分や 子どものために活動に参加した。活動を続けている中でその社会的意義に気がつき、外に 発信する側となっていく、まさに主体化の過程が見られた。Sさんはさらに、プレーパー クでの経験を元に、小学校での地域を巻き込んだ校庭づくりの活動を展開させる。プレー パークでの経験を持つ人びとが、例えば老人給食や遊び場マップづくりなど、自分の興味 関心の中で新しい活動を展開する事例は枚挙にいとまがない。担い手のネットワークは、 
地域の他の活動に参画したり、新しい活動を始めたりすることで、他の特殊的課題解決型 のネットワークに接続していく。こうした担い手のネットワークの拡がりも、アソシエー ションが他のアソシエーションとネットワークを形成し、ネットワーク型コミュニティを 成立させていくことに寄与している。そして活動の担い手が、従来型の地域住民組織を中 心とした地域コミュニティとの橋渡し役を担っていることも、Sさんの事例から読み取る ことができる。

\section{3. 地域外に拡がるネットワーク}

\section{1 プレーパーク活動と国際的なネットワーク}

地域内でのネットワーク型コミュニティが成立してきた過程と並行して、世田谷のプ レーパーク活動は、地域外の子どもの遊びに関する活動を行う人びとおよび組織とも連携 してきた。子どもの遊びに関するネットワークの源泉として、IPA ${ }^{6)}$ (International Playground Association）の存在が大きい。そもそも冒険遊び場の嗃矢はデンマークのコペンハーゲン につくられた「エンドラップ廃材遊び場」であつた。この場所を『都市の遊び場』の著者 であるアレン卿夫人が訪問し、その理念をイギリスで実践し紹介したことで、ヨーロッパ 中に拡がっていつた [羽根木プレーパークの会, 1987]。子どもの遊びや遊び場づくりを、

こうして問題として捉えた人びとの働きかけにより、1959年に採択された国連の「児童の 権利宣言」に「子ぞもの遊ぶ権利」が盛り込まれた。そして、アレン卿夫人やデンマーク の遊び場協会が中心となり、1961年に子どもの遊ぶ権利の実現を目指して創設されたのが IPA である。その後IPAはユネスコの諮問機関となり、各国の子どもの遊びの環境向上に 大きな役割を果たしてきた。1982年にIPAが発表した「子どもの遊ぶ権利宣言」は、1989 年に国連が採択した「子どもの権利条約」にも大きな影響を与え、第31条に「子どもの 遊ぶ権利」が取り入れられている [大村編, 2009]。

1994 年に日本が「子どもの権利条約」を批准し、各自治体が子どもの権利実現のために 制定した条例でも、子どもの遊ぶ権利について触れられている。川崎市の「川崎子ども夢 パーク」は、子どもや市民を含めたワークショップを経て企画され、「プレーパークエリ ア」を配置した子どもたちが自由に遊べる施設として開設された。これも、子どもの権利 として「遊ぶこと」が明記されている「川崎市子どもの権利に関する条例」によるものと 考えられる [大村編, 2009]。このように、プレーパークや冒険遊び場活動を含んだ子ども の遊びに関する国際的な運動が、国際的なコンセンサスや制度をつくり出すことによつ て、日本の地域にも影響を及ぼしているのである。

世田谷のプレーパーク活動はこのようなIPAの活動にも共鳴してきた。プレーパークの 創設に中心的な役割を果たした大村璋子氏は、『都市の遊び場』でIPAの存在を知り、そ の後1978年のオタワでの世界大会に参加して、経堂や桜丘の遊び場の様子をスライドショー 
で発表した。当時、世界的にみて市民だけで冒険遊び場を運営している事例はめずらし く、資金についての質問などが出たという。その後1979年の国際児童年に、イギリスか らIPA 事務局長が来日して羽根木公園を視察したことが、羽根木公園でのプレーパーク開 設を後押しした。この時、日本各地のIPA会員や遊び場づくりに関わる人たちが集まり、 IPA 日本支部を発足させ、代表は大村璋子氏が務めた。IPA 日本支部が発足したことで、 子どもの遊びに関するネットワークが日本国内で拡がると同時に、遊びの環境づくりにつ いての関心が、造園、建築、都市計画、美術や教育など多様な分野の研究者や専門家たち にも拡がった。1990年には東京でIPAの世界大会を開催し、子どもの視点での遊び場づく り、まちづくりなどが議論され、子どもを含む市民が、遊びの環境づくりに参加するため のワークショップの手法なども紹介された [大村編, 2009]。こうしたIPA とのネットワー クは、これを通じて行ったアメリカ視察により「世田谷まちづくりファンド」の構想が生 まれるなど、世田谷のまちづくりにも大きな影響を与えてきた。

\section{2 プレーパークの全国的ネットワーク一全国組織の設立と被災地支援}

プレーパークは新聞や雑誌などマスメディアで紹介されることも多く、開設当初から全 国の団体や個人が視察に多数訪れた7)。プレーパーク前身の冒険遊び場時代から、遊び場 を訪問した後自分たちの地域で冒険遊び場を実践する例があり、世田谷ではじまったプ レーパークは全国に活動が派生していった [羽根木プレーパークの会, 1987]。世田谷で世 話人やプレーリーダーを担い、他の地域でプレーパーク設立や子どもの遊びに関わる活動 を行っている人も多い。

1998年に羽根木プレーパークの 20 周年を記念した冒険遊び場の全国研究集会が開催さ れた。これまで視察に訪れた人びとなどに呼びかけて、全国約 60 団体、400名の参加者が 集まった。この時研究集会を主催した実行委員会で、各地の活動を支援する全国組織の必 要性が議論され、設立への機運が高まった。1999年にIPA 日本支部内に「冒険遊び場情報 室」が開設され、これを母体として 2003 年にNPO法人日本冒険遊び場づくり協会が設立 された [大村編, 2009]。日本冒険遊び場づくり協会は、遊び場活動を行う団体を支援する 中間支援組織であり、新しい遊び場の立ち上げ支援などを行っている。NPO法人設立直 後の 2004 年には全国で冒険遊び場活動を行っている団体は 192 団体であったが、10年後の 2014 年には約 400 団体にまで増加している [NPO 法人日本冒険遊び場づくり協会, 2017]。

このような全国的なネットワークがどのような力を発揮するのか。これがわかる一例が 被災地支援である。まだ全国組織ができていなかった 1995 年の阪神・淡路大震災の折、 当時の世田谷区内のプレーパーク連絡組織であった「せたがやプレーパーク連絡協議会」 は、プレーリーダーを被災地に派遣した。きっかけは、大震災発生後にプレーパークに来 ていた子どもたちが、「テレビが地震のニュースばかりでつまらない」と言つたことだっ た。自分たちが現地に行き見て聞いて活動してくれば、他人事ではなくなるのではないか 
という思いを持ち、プレーリーダーが現地へ支援に行くことになったのである。世田谷ボ ランティア協会を通じて被災地で活動するボランティア団体を調べ、主にアジアの子ども たちに教育支援を行っているSVA（曹洞宗国際ボランティア協会、現在は社団法人シャン ティ国際ボランティア協会) の神戸での救援活動に合流することになった。軽ワゴン車に 普段から使っている工作や大工道具を積み、状況が許せば遊び場をつくろうということ で、滑車ロープ用の滑車も持って行つた。1月 26 日にSVAと合流し、小学校の救援物資の 整理など支援活動を行った [第 3 回冒険遊び場全国研究集会実行委員会, 2005]。

その後避難テントがなく空きスペースのある公園を見つけ出し、遊び場活動を始めたの が地震発生から 2 週間後の 2 月 3 日であつた。震災から 1 か月がたつた頃、大人は被災体 験を話しはじめたが、子どもは自分の心を語る言葉を持ち合わせていない。2 か月ほど たつた頃、積夕木を重ねては「震度 7 だ」と言つて何度も壊したり、新聞紙に火をつけて 「まちが燃えている」と叫んだりするような「震災ごつこ」が流行した。被災した大人に とって不愉快なこの遊びこそが、子どもたちにとつては話すことと同じように被災体験を 表現する手段であり、乗り越えようとしている表れだつた。被災地では子どもへの気づか いは二の次になりがちであるが、子どもは遊びを通じて自分を自由に表現し、自らを癒す ことができる。だからこそ遊び場が必要だ。このことが、この時の被災地での遊び場活動 で明確になった [天野, 2011]。

そしてこの経験は、2011年の東日本大震災の復興支援に引き継がれる。東日本大震災発 生以降、日本冒険遊び場づくり協会が中心となって遊び場づくりによる復興支援を行って きた。阪神・淡路大震災の時にも共に活動したSVAが、緊急救援に入つていた気仙沼に 今回も合流した。4月初旬に初めて気仙沼の調査に入り、小学校を訪ねて地区の振興会長 を紹介してもらった。その仲介で 2 人の地主が土地を提供してくれることになり、遊び場 を開設するための準備を始めた。小学校で遊び場の宣伝をさせてもらうと、それから毎日 のように子どもたちが手伝いに来るようになり、遊び場がオープンした 4 月 26 日には、50 人もの子どもがやってきた。その後、「震災ごっこ」は気仙沼でも見られ、「来たぞー」と 言つて逃げる子どもを、津波のまねをした子どもが追いかけて取り囲んだ。都市部である 神戸の経験と異なっていたのは、子どもが元気になってうるさくなってきても、迷惑施設 にならなかったことだった [天野, 2011]。

遊び場は「あそびーばー」と名づけられ、日本冒険遊び場づくり協会を中心に全国のネッ トワークで寄付を募って運営した。各地の経験豊富なプレーリーダーが交代で常駐し、遊 び支援、地域における関連活動の支援を行い、地域コミュニティと連携しながら復興を支 えた。この活動は、遊びを通した子どもの回復だけでなく、遊び場づくりを通してこれに 賛同する大人たちのネットワークが構築され、コミュニティの回復にもつながつた。日本 冒険遊び場づくり協会が開設し運営していた「気仙沼あそびーばー」は、2012年 8 月から 地域住民による運営に移行している [NPO 法人日本冒険遊び場づくり協会, 2014]。 
NPO 法人プレーパークせたがやからも 2011 年度に気仙沼の遊び場へプレーリーダーと 世話人 7名をのべ70日間派遣した。2011年 8 月から、仙台でプレーカーを被災地に走らせ て、あちこちで遊び場づくりを通した支援を行う活動にも、プレーリーダーを長期派遣し てきた [NPO法人プレーパークせたがや, 2012・2013]。プレーカー事業はその後も継続 され、2013年度には 1 台のプレーカーで、被災三県の16か所のべ116日間遊び場を開催し た。日本ユニセフ協会の支援でプレーカー 2 台が追加され、運行を行うプレーリーダーの 人件費が保障されることになり、さらに各地での遊び場活動が展開している。こうした活 動により、震災前には東北で 5 か所程度しかなかつた遊び場活動が、2013年の時点で 30 か所近くにまで増えている [NPO法人日本冒険遊び場づくり協会, 2014]。

プレーカーで被災した多数の地域で遊び場を開設する中で、子どもたちを取り巻く生活 環境の厳しさにプレーリーダーは気がついていく。津波被害にあった小学校の統合で、不 安になる 2 校の子どもたちが、遊び場で交わることで不安が解消される。子どもたちが思 い切り遊べない仮設住宅での遊び場開設により、子どもの遊ぶ声が、お互い交流のなかつ た大人たちを外に連れ出す。このように、遊び場の成果は子どもの遊び場の確保にとどま るものではない ${ }^{8)}$ 。復興庁の「新しい東北」先導モデル事業で、プレーワーカー(プレー リーダー）を育成するためのプログラム開発を行い、この参加者が日本冒険遊び場づくり 協会の東北オフィスを担い、プレーカーの運用をはじめとする復興支援事業の地域拠点を 担ってきた。この東北オフィスが 2016 年 4 月から一般社団法人プレーワーカーズとして 独立した。これには、復興支援を長期的に行っていく姿勢があらわれている。

以上に見てきたように、世田谷から始まったプレーパークの活動は全国に派生し、全国 組織を立ち上げるまでに成長した。またこのネットワークは、子どもの遊びや遊び場の運 営という主題を通して、震災で危機に陥つた地域を支援し、その地域のコミュニティ再生 にも貢献している。子どもたちの遊びに関する活動から、なぜ他の問題にまで関心が拡が るのか。その核心が、次のようなプレーリーダーの言葉に表れている。プレーパークが常 設で運営されることで、子どもたちの生活の一部に遊び場が組み込まれ、これに関わるプ レーリーダーや大人たちに、子どもの生活が見えてくる。そして、子どもたちの環境や置 かれている状況が見えて、それを社会に発信していけるようになる [第 3 回冒険遊び場全 国研究集会実行委員会, $2005: 33]$ 。このように、プレーリーダーや運営者が、活動の中 で子どもが抱える問題に気がついていくことが、活動の幅を拡げネットワーク型コミュニ ティを成立・拡大させていく。被災地での遊び場の展開は、遊びや遊び場の問題を主題と した子どもに関するネットワーク型コミュニティの力が発揮された一例に過ぎない。活動 における気づきによって、例えばプレーリーダーが今では全国的に拡がるチャイルドライ ンの日本での設立に関わる [天野, 2002] など、他の活動への拡がりやネットワークを持 つことにつながるのである。 


\section{4. 結論}

特殊的課題解決型の市民活動やNPOが、地域内外でネットワーク型コミュニティをど のように形成していき、どのような力を発揮するのかについてこれまで検討してきた。2 節では、特殊的課題解決型のアソシエーションが他の問題をも取り込むことによって、地 域の中でネットワーク型コミュニティを形成していることを確認した。これは奥田や越智 が描いていた新しく形成される地域コミュニティを、市民活動やNPOの側から捉え直し たものと位置づけることができる。しかし、先に指摘しておいたように、ネットワーク型 コミュニティは地域の中にとどまっていないことが最大の特徵となる。日本では世田谷で 始まつた冒険遊び場活動は、世界的な動向から飛び火してきた 1 つの事例として捉えるこ とができる。子どもの遊ぶ環境づくりを目指す国際的な取り組みの中心的存在であるIPA は、国際的なコンセンサスや制度をつくることによって、日本の地域にも影響を及ぼして きた。世田谷のプレーパーク活動とIPAとの連携は、日本国内の子どもの遊びに関わる ネットワークを増幅させ、世田谷のまちづくりにも影響を及ぼした。

一方で、プレーパーク活動は、日本国内においても全国に活動が拡がつていった。2 節 で詳細に見てきたような地域におけるネットワーク型コミュニティが、全国各地に (その 規模は様々であるとしても）生成しているものと考えることができ、またこれが全国的な ネットワークでつながっているのである。そしてこの全国的なネットワークは、特殊的課 題解決のみを目的にしたアソシエーションにとどまらず、他の問題を取り込み大きなネッ トワーク型コミュニティを形成している。その転換のポイントは、子どもを取り巻く他の 問題をも解決しないかぎり、遊びや遊び場の問題を解決できないからである。阪神・淡路 大震災、東日本大震災後の支援活動の事例にもこのことが表れる。子どものために遊び場 を被災地で開設するが、子どもたちの様子には被災の経験、家族の問題、家族を取り巻く 地域コミュニティの問題が表れる。「子どもを自由に遊ばせる」という目的のために、プ レーリーダーは子どもの遊びに関わるだけでなく、家族支援やコミュニティ再生の取り組 みに着手せざるを得ない。このことが、東北での長期的な活動を前提とした一般社団法人 設立に表れているのである。

2 節で検討したような地域の中に成立している特殊的課題解決を目的としたネットワー ク型コミュニティは、全国的あるいは世界的に点在しており、これらがネットワークで結 ばれている形状が、ネットワーク型コミュニティの全体像だと考えることができる。そし て、被災地支援の事例に代表されるように、問題を抱えた人びとや地域に対し、そのネッ トワークを使って支援をするなどの力を発揮し、そこからまた増殖していくものと予測で きる。ネットワーク型コミュニティは網の目の形状をしており、網の目が細かいところほ ど、ネットワークに参加していなくてもその恩恵を受けやすいものと考えられる。しか し、ここに蓄積されているソーシャル・キャピタルは、ネットワークに参加する人や組織 
の相互行為によって醸成されているのであり、いつまでもなくならずに存在しているもの ではない。世田谷のプレーパークは活動を継続することによって、このネットワーク型コ ミュニティ形成の一部を担い、全国・世界に拡がる大きなネットワークと世田谷の地域コ ミュニティのネットワークを連結させていると考えることができる。この橋渡し役を担つ ているのは、NPO法人組織とこれに関わる人びとである。この橋渡し機能によって世田 谷の地域も、全国・世界に拡がっているその資源を活用できるのである。

ソーシャル・キャピタル論の議論を借りれば、ネットワークに組み込まれその存在に気 がついている場合に、ネットワーク上の資源を引き出すことができる [Lin, $2001=2008]$ 。 それゆえ、プレーパークが持つ地域にとどまらないネットワークからもたらされる資源 を、ある意味では、世田谷の地域からみて使用可能な資源として勘案しておくことが必要 となる。このように地域の外に拡がる資源を地域の中からも正当に評価し、これをどのよ うに増やしていくか、どのように活用していくかという視点が、地域格差、地域創生が言 われる時代に重要なものの1つとなるのではないだろうか。

\section{注}

1）2012年に「地域保健対策の推進に関する基本的な指針」が一部改正され、「ソーシャル・ キャピタルを活用した自助及び共助の支援の推進」が追加された。

2）吉原直樹は、避難の際には地域コミュニティに依存せず、家族や親せきをともなって自分た ちの車で避難するのが自然な行動であったことを指摘している [吉原, 2013]。

3）地域の外から入ってくるボランティアやNPOの支援はこの典型であると考えられる。

4）国民生活審議会調査部会コミュニティ問題小委員会 [1969] がその嚆矢とされる。これを受 ける形で 1970 年代はコミュニティ研究が隆盛を極めた。

5） 2013 年 7 月 23 日に 2 時間ほど聞き取りを行った。より詳しい記述は小山弘美 [2018]を参照。

6） 1981年に正式名称を International Play Association一Promoting the Child Right to Playに変更 した。

7）羽根木プレーパークだけでも 1 年で 100 件 1200 人を超える視察や見学が訪れている [NPO法 人プレーパークせたがや羽根木プレーパーク, 2013]。

8） 2013 年 10 月 28 日プレーパークせたがや報告会「冒険遊び場一せんだい・みやぎネットワー クが遊び場に取り組んでいるのは‥」より。

\section{参考文献}

天野秀昭, 2002, 『子どもはおとなの育ての親』ゆじょんと.

2011, 『よ夕がえる子どもの輝く笑顔』すばる舎.

第 3 回冒険遊び場全国研究集会実行委員会, 2005, 『第 3 回冒険遊び場全国研究集会報告書—つ ながりをつなげよう』.

羽根木プレーパークの会編, 1987, 『冒険遊び場がやってきた !一一羽根木プレーパークの記録』 晶文社.

国民生活審議会調査部会コミュニティ問題小委員会, 1969, 『コミュニティ一生活の場におけ る人間性の回復』.

今野裕昭, 1999, 「震災対応とコミュニティの変容——神戸市真野地区」岩崎信彦他編『阪神・ 
淡路大震災の社会学——被災と救援の社会学』昭和堂, 204-15.

小山弘美, 2018, 『自治と協働からみた現代コミュニティ論—世田谷区まちづくり活動の軌跡』 晃洋書房.

倉田和四生, 1999, 『防災福祉コミュニティ—地域福祉と自主防災の統合』ミネルヴァ書房.

Lady Allen of Hurtwood, 1968, Planning for Play, London: Thames \& Hudson. (=1973, 大村虔 一・大村璋子訳『都市の遊び場』鹿島出版会. )

Lin, N., 2001, Social Capital: A Theory of Social Structure and Action, New York: Cambridge University Press. (=2008, 筒井淳也他訳『ソーシャル・キャピタル—社会構造と行為の理論』ミ ネルヴァ書房. )

Lipnack, J. and Stamps, J., 1982, NETWORKING, New York: Doubleday \& Company Inc. (=1984, 社会開発統計研究所訳『ネットワーキング』プレジデント社. )

NPO 法人プレーパークせたがや, $2012 ・ 2013$, 『事業報告書』.

NPO法人プレーパークせたがや研修センター, 2013, 『冒険遊び場づくり物語—子どもの豊か な育ちを実現するため、住民と行政が取り組んだ日本で初めての挑戦』.

NPO 法人プレーパークせたがや羽根木プレーパーク，2013，『2012年度羽根木プレーパーク活動 報告書』。

NPO 法人日本冒険遊び場づくり協会, 2014, 「第11回通常総会議案書」, (2017年11月 27 日取得, http://bouken-asobiba.org/assets/attach/0000/060000170428_102210.pdf).

NPO 法人日本冒険遊び場づくり協会, 2017「全国の活動団体数の推移」，（2017年11月 27 日取得, http://bouken-asobiba.org/know/transition.html).

越智 昇，1982，「コミュニティ経験の思想化」奥田道大他『コミュニティの社会設計一一新し い〈まちづくり〉の思想』有斐閣, 135-77.

—， 1986，「都市における自発的市民活動」『社会学評論』Vol.37, No.3, 272-92.

大村璋子編著, 2009, 『遊びの力——遊びの環境づくり 30 年の歩みとこれから』萌文社.

奥田道大, 1971，「コミュニティ形成の論理と住民意識」磯村英一・鵜飼信成・川野重任編『都 市形成の論理と住民』東京大学出版会, 135-77.

， 1975，「都市住民運動の展開とコミュニティ理念」国民生活センター編『現代日本の コミュニティ』川島書店, 55-93.

Putnam, R.D., 2000, Bowling Alone: The Collapse and Revival of American Community, New York: Simon \& Schuster. (=2006, 柴内康文訳『孤独なボウリング——米国コミュニティの崩壊 と再生』柏書房. )

世田谷区，2017，「統計書平成 28 年人口編」.

高田昭彦，1998，「現代市民社会における市民運動の変容—ネットワーキングの導入から『市 民活動』・NPOへ」青井和夫・高橋 徹・庄司興吉編『現代市民社会とアイデンティ ティ』梓出版社, 160-85.

Wellman, B., 1979, “The Community Question: The Intimate Networks of East Yorkers,” American Journal of Sociology, 84: 1201-31.（=2006, 野沢慎司・立山徳子訳「コミュニティ問 題一イースト・ヨーク住民の親密なネットワーク」野沢慎司編・監訳『リーディングス ネットワーク論』勁草書房, 159-204.)

吉原直樹, 2013,「地域コミュニティの虚と実——避難行動および避難所からみえてきたもの」 田中重好・舩橋晴俊・正村俊之編著『東日本大震災と社会学一大災害を生み出した社 会』ミネルヴァ書房, 47-69. 